\title{
Front Matter: Volume 9171
}

, "Front Matter: Volume 9171," Proc. SPIE 9171, Nanobiosystems:

Processing, Characterization, and Applications VII, 917101 (7 October 2014); doi: $10.1117 / 12.2081265$

SPIE Event: SPIE NanoScience + Engineering, 2014, San Diego, California, United SPIE. States 


\title{
PROCEEDINGS OF SPIE
}

\section{Nanobiosystems: Processing, Characterization, and Applications VII}

\author{
Norihisa Kobayashi \\ Fahima Ouchen \\ lleana Rau \\ Editors
}

18-20 August 2014

San Diego, California, United States

Sponsored and Published by

SPIE 
The papers included in this volume were part of the technical conference cited on the cover and title page. Papers were selected and subject to review by the editors and conference program committee. Some conference presentations may not be available for publication. The papers published in these proceedings reflect the work and thoughts of the authors and are published herein as submitted. The publisher is not responsible for the validity of the information or for any outcomes resulting from reliance thereon.

Please use the following format to cite material from this book:

Author(s), "Title of Paper," in Nanobiosystems: Processing, Characterization, and Applications VII, edited by Norihisa Kobayashi, Fahima Ouchen, lleana Rau, Proceedings of SPIE Vol. 9171 (SPIE, Bellingham, WA, 2014) Article CID Number.

ISSN: 0277-786X

ISBN: 9781628411980

\section{Published by}

\section{SPIE}

P.O. Box 10, Bellingham, Washington 98227-0010 USA

Telephone +1 3606763290 (Pacific Time) · Fax +1 3606471445

SPIE.org

Copyright @ 2014, Society of Photo-Optical Instrumentation Engineers.

Copying of material in this book for internal or personal use, or for the internal or personal use of specific clients, beyond the fair use provisions granted by the U.S. Copyright Law is authorized by SPIE subject to payment of copying fees. The Transactional Reporting Service base fee for this volume is $\$ 18.00$ per article (or portion thereof), which should be paid directly to the Copyright Clearance Center (CCC), 222 Rosewood Drive, Danvers, MA 01923. Payment may also be made electronically through CCC Online at copyright.com. Other copying for republication, resale, advertising or promotion, or any form of systematic or multiple reproduction of any material in this book is prohibited except with permission in writing from the publisher. The CCC fee code is 0277-786X/14/\$18.00.

Printed in the United States of America.

Publication of record for individual papers is online in the SPIE Digital Library.

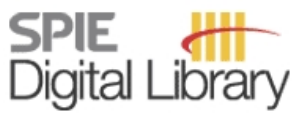

SPIEDigitalLibrary.org

Paper Numbering: Proceedings of SPIE follow an e-First publication model, with papers published first online and then in print and on CD-ROM. Papers are published as they are submitted and meet publication criteria. A unique, consistent, permanent citation identifier (CID) number is assigned to each article at the time of the first publication. Utilization of CIDs allows articles to be fully citable as soon as they are published online, and connects the same identifier to all online, print, and electronic versions of the publication. SPIE uses a six-digit CID article numbering system in which:

- The first four digits correspond to the SPIE volume number.

- The last two digits indicate publication order within the volume using a Base 36 numbering

system employing both numerals and letters. These two-number sets start with 00, 01, 02, 03, 04, 05, 06, 07, 08, 09, 0A, 0B ... 0Z, followed by 10-1Z, 20-2Z, etc.

The CID Number appears on each page of the manuscript. The complete citation is used on the first page, and an abbreviated version on subsequent pages. Numbers in the index correspond to the last two digits of the six-digit CID Number. 


\title{
Contents
}

\author{
$\checkmark$ Authors \\ vii Conference Committee
}

\section{MISCELLANEOUS I}

917103 Electrical conductivity and impedance behaviour of hydrogels (Invited Paper) [9171-2]

\section{DNA PHOTONICS I}

917107 Deoxyribonucleic acid-Ag nanoparticles for EMI Shielding: the effect of nanoparticle size, shape and distribution on the shielding effectiveness [9171-6]

\section{DNA PHOTONICS II}

$91710 \mathrm{C}$ Investigation of a DNA nucleobase as a gate dielectric for potential application in a graphene-based field effect transistor [9171-11]

9171 OE Hyper Rayleigh scattering of biomolecules: the case of thymine and adenine (Invited Paper) [9171-13]

9171 OF Natural materials for nano bio systems (Invited Paper) [9171-16]

\section{DNA PHOTONICS III}

$91710 G$ Light amplification and lasing from dyes doped in DNA-complex thin films prepared by soaking method (Invited Paper) [9171-14]

$9171 \mathrm{OH}$ Random lasing in dye doped bio-organic based systems: recent experiments and stochastic approach (Invited Paper) [9171-15]

$91710 \mathrm{~J}$ Summary report on AFRL studies of the optical and electrical properties of biopolymers using salmon DNA (Invited Paper) [9171-32]

\section{MISCELLANEOUS II}

9171 ON Photo-Seebeck effect of conjugated polymers (Invited Paper) [9171-21]

917100 Micro and nanostructuration of polymer materials and applications (Invited Paper) [9171-22] 
9171 OP Diatom frustule photonic crystal geometric and optical characterization [9171-23]

$9171 \mathrm{OQ} \quad$ Novel $\mathrm{pH}-$ sensitive probes with a ratiometric detection for intracellular $\mathrm{pH}$ [9171-24]

\section{POSTER SESSION}

9171 OS Hyper Rayleigh and hyper Raman from neat water [9171-25]

$91710 \mathrm{U}$ Viral-templated nanocrystalline Pd nanowires for chemiresistive hydrogen $\left(\mathrm{H}_{2}\right)$ sensors [9171-27]

9171 OV Physicochemical characterization of silver nanoparticles synthesize using Aloe Vera (Aloe barbadensis) [9171-28]

9171 OW Toward a chemiresistive ammonia $\left(\mathrm{NH}_{3}\right)$ gas sensor based on viral-templated gold nanoparticles embedded in polypyrrole nanowires [9171-29]

$91710 X \quad$ Morphology manipulation of M13 bacteriophage template for nanostructure assembly [9171-30]

9171 oY Second harmonic generation from silver nanoparticles in aqueous solution with different protective agents [9171-31]

$91710 Z$ Investigations of molecular nonlinear optical polarizabilities of azobenzenes substituted with strong acceptor groups [9171-34] 


\title{
Authors
}

Numbers in the index correspond to the last two digits of the six-digit citation identifier (CID) article numbering system used in Proceedings of SPIE. The first four digits reflect the volume number. Base 36 numbering is employed for the last two digits and indicates the order of articles within the volume. Numbers start with $00,01,02,03,04,05,06,07,08,09,0 A, 0 B . .0 Z$, followed by 10-1Z, 20-2Z, etc.

\author{
Alverson, Andrew J., OP \\ Andraud, Chantal, $O Q$ \\ Benichou, Emmanuel, OE, OS \\ Bertorelle, Franck, $\mathrm{OE}$ \\ Billon, Cyrielle, $O Q$ \\ Blake, Phillip, OP \\ Bretonnière, Yann, $0 Q$ \\ Brevet, Pierre-François, OE, OS \\ Canto, Fabrice, OS \\ Couston, Laurent, OS \\ Cyprych, $\mathrm{K} ., \mathrm{OH}$ \\ Do, Mai Trang, 00 \\ Elhamri, Said, OC \\ Gomez, Eliot, OF \\ Grote, James G., 07, OC, OF, OJ \\ Haberer, Elaine D., OU, OW, OX \\ Herzog, Joseph B., OP \\ lisaka, You, OG \\ in het Panhuis, Marc, 03 \\ Ipuy, Martin, $0 Q$ \\ Jerca, Florica Adriana, $\mathrm{OZ}$ \\ Jerca, Valentin Victor, $\mathrm{OZ}$ \\ Joyce, Donna, OF \\ Kajzar, Francois, $\mathrm{OH}, \mathrm{OZ}$ \\ Kassama, Lamin, OV \\ Kawabe, Yutaka, OG \\ Kieu, Duy Manh, 00 \\ Kim, B., ON \\ Kim, E., ON \\ Kim, Steve, OC \\ Kozlowski, Gregory, OC \\ Kukhtareva, Tatiana, OV \\ Kuponiyi, Abiola, OV \\ Lai, Ngoc Diep, 00 \\ Ledoux-Rak, Isabelle, 00, 0 Y \\ Li, Qinggele, 00 \\ Lim, H., ON \\ Luong, Mai Hoang, 00 \\ Ma, Qianli, OS \\ Maurice, Anthony, OE, OS \\ Micouin, Guillaume, $\mathrm{OQ}$ \\ Mishler, Jonathan, $\mathrm{OP}$ \\ Mitus, A. C., $\mathrm{OH}$ \\ Moon, Chung-Hee, OU, OX \\ Mou, Shin, OC \\ Mysliwiec, J., $\mathrm{OH}$ \\ Myung, Nosang $\mathrm{V}_{\text {., }}$ OU, OW \\ Naik, Rajesh R., OC \\ Ngo, Hoang Minh, OY
}

\author{
Ngo, Yen H., OC \\ Ngo-Duc, Tam-Triet, OX \\ Nguyen, Dam Thuy Trang, 00 \\ Nguyen, Thi Thanh Ngan, 00 \\ Ouchen, Fahima, 07, OC, OF, OJ \\ Pawlik, G., $\mathrm{OH}$ \\ Rau, lleana, $\mathrm{OH}, \mathrm{OZ}$ \\ Roper, D. Keith, OP \\ Russier-Antoine, Isabelle, OS \\ Salour, Michael M., 07 \\ Samarut, Jacques, $O Q$ \\ Su, Heng Chia, OW \\ Subramanyam, Guru, OF \\ Suzuki, Takemasa, OG \\ Sznitko, L., $\mathrm{OH}$ \\ Szukalski, A., $\mathrm{OH}$ \\ Tong, Quang Cong, $0 \mathrm{O}$ \\ Vasilescu, Dan Sorin, $0 Z$ \\ Vuluga, Dumitru Mircea, $0 Z$ \\ Warren, Holly, 03 \\ Williams, Adrienne D., OC, OF \\ Wilson, Benjamin G., 07 \\ Yan, Yiran, OU, OW \\ Yaney, Perry P., 07, OF, 0J \\ Zaman, Mohammed Shahriar, OX \\ Zhang, Miluo, OU, OW
}


Proc. of SPIE Vol. $9171917101-6$

Downloaded From: https://www.spiedigitallibrary.org/conference-proceedings-of-spie on 26 Apr 2023 Terms of Use: https://www.spiedigitallibrary.org/terms-of-use 


\section{Conference Committee}

Symposium Chairs

Satoshi Kawata, Osaka University (Japan)

Manijeh Razeghi, Northwestern University (United States)

Symposium Co-chairs

David L. Andrews, University of East Anglia Norwich (United Kingdom) James G. Grote, Air Force Research Laboratory (United States)

Conference Chairs

Norihisa Kobayashi, Chiba University (Japan)

Fahima Ouchen, Air Force Research Laboratory (United States)

Ileana Rau, Polytechnical University of Bucharest (Romania)

Conference Program Committee

Carrie M. Bartsch, Air Force Research Laboratory (United States) Liming Dai, Case Western Reserve University (United States)

Ananth Dodabalapur, The University of Texas at Austin (United States) James G. Grote, Air Force Research Laboratory (United States)

Emily M. Heckman, Air Force Research Laboratory (United States)

Kuniharu ljiro, Hokkaido University (Japan)

Jung-II Jin, Korea University (Korea, Republic of)

Francois Kajzar, Polytechnical University of Bucharest (Romania)

Sang Nyon Kim, Air Force Research Laboratory (United States)

Oksana Krupka, Université d'Angers (France)

Charles Y. C. Lee, Air Force Office of Scientific Research (United States)

Misoon Y. Mah, Asian Office of Aerospace Research and Development (Japan)

Naoya Ogata, Chitose Institute of Science and Technology (Japan)

Bruce H. Robinson, University of Washington (United States)

Anna Samoc, The Australian National University (Australia)

Marek J. Samoc, Wroclaw University of Technology (Poland)

Niyazi Serdar Sariciftci, Johannes Kepler Universität Linz (Austria)

Kristi M. Singh, Air Force Research Laboratory (United States)

Andrew J. Steckl, University of Cincinnati (United States)

Morley O. Stone, Air Force Research Laboratory (United States)

Perry P. Yaney, University of Dayton (United States) 
Session Chairs

1 Miscellaneous I

Norihisa Kobayashi, Chiba University (Japan)

2 DNA Photonics I

Donna M. Joyce, Air Force Research Laboratory (United States)

3 DNA Photonics II

Fahima Ouchen, Air Force Research Laboratory (United States)

4 DNA Photonics III

Pierre-François Brevet, Université Claude Bernard Lyon 1 (France)

5 DNA Photonics IV

Fahima Ouchen, Air Force Research Laboratory (United States)

6 Miscellaneous II

Ileana Rau, Polytechnical University of Bucharest (Romania)) 